\title{
HEALING LANDSCAPES: THE EFFECTS OF ITS PARAMETERS ON DIFFERENT GENDER (CASE STUDY: ERAM GARDEN \& AZADI PARK OF SHIRAZ-IRAN)
}

\author{
Mina Razmara*1, Hajar Asadpour², Malihe Taghipour ${ }^{3}$ \\ Architecture, Shiraz Branch, Islamic Azad University, Shiraz, Iran ${ }^{1}$ \\ Urban Design, Yazd University, Yazd, Iran ${ }^{2}$ \\ Architecture, Shiraz Branch, Islamic Azad University, Shiraz, Iran ${ }^{3}$ \\ E-mail: *1m_razmara_ar@yahoo.com, ${ }^{2}$ sharareh_asadpour@yahoo.com, ${ }^{3}$ malihe_taghipour_ar@yahoo.com
}

\begin{abstract}
Abstrak_ Lanskap penyembuhan menciptakan ruang yang membantu orang mengurangi stres dan meningkatkan kesehatan mental mereka. Dalam budaya Iran, taman bersejarah serta taman kota (dalam beberapa dekade terakhir) dapat bermanfaat untuk menciptakan lanskap penyembuhan. Mempertimbangkan model Canter Place, parameter lanskap penyembuhan disajikan dalam bentuk tiga dimensi: fungsional, persepsi-semantik, dan fisikvisual. Karena pria dan wanita berperilaku berbeda dalam menghadapi lingkungan mereka, penelitian ini mengevaluasi bagaimana taman Persia dan taman kota berpengaruh (dengan dua pola struktural yang berbeda) di antara pria dan wanita. Metode penelitian adalah kuantitatif, dan data dikumpulkan dengan teknik kuesioner. Kemudian, analisis varian variabel Unianova tunggal dalam perangkat lunak SPSS 23 digunakan untuk mengevaluasi data. Hasil penelitian menunjukkan bahwa tidak ada perbedaan dalam persepsi dimensi dalam penyembuhan antara pria dan wanita. Pemahaman seorang wanita tentang dimensi penyembuhan persepsisemantik dan fungsional di Azadi Park berbeda dan kurang dari pria. Di Taman Eram, tidak seperti Taman Azadi, tidak banyak perbedaan antara kegiatan pria atau wanita. Secara umum, umpan balik wanita lebih rendah daripada pria, pada parameter penyembuhan lingkungan Azadi Park (struktur lanskap organik). Oleh karena itu, perlu untuk lebih memperhatikan inklusivitas gender dari lanskap penyembuhan perkotaan dalam desain.
\end{abstract}

Kata kunci : Lanskap Penyembuhan; Taman Persia; Taman Kota; Taman Shiraz Eram; Jenis Kelamin.

\begin{abstract}
Healing Landscapes are spaces that help people to reduce their stress and improve their mental health. In Iranian culture, historic gardens and urban parks (in recent decades) can be useful to create healing landscapes. Considering the Canter Place model, the parameters of landscape healing presented in the form of three dimensions: functional, perceptual-semantic, and physical-visual. Since men and women behave differently in dealing with their surroundings, this research evaluates how Persian gardens and urban parks effect (with two different structural patterns) among men and women. The research method was quantitative, and data gathered by the questionnaire technique. Then, Unianova single-variable analysis of variance test in SPSS 23 software was used to evaluate the data. The results indicated no difference in the perception of the physical-visual dimension of healing between men and women. A woman's understanding of the perceptional-semantic and functional dimension of healing in Azadi Park was different and less than men. In Eram Garden, unlike Azadi Park, there was not much difference between of men or women's activities. In general, women's feedback is lower than men, on the environment healing parameters of Azadi Park (organic landscape structure). Therefore, it is necessary to pay more attention to the gender inclusiveness of urban healing landscapes in design.
\end{abstract}

Keywords: Healing Landscape; Persian Garden; Urban Park; Shiraz Eram Garden; Gender.

\footnotetext{
${ }^{1}$ Architecture, Shiraz Branch, Islamic Azad University, Shiraz, Iran

2 Urban Design, Yazd University, Yazd, Iran

${ }^{3}$ Architecture, Shiraz Branch, Islamic Azad University, Shiraz, Iran
} 


\section{INTRODUCTION}

In the mid and late twentieth centuries, access to nature and the therapeutic value of gardens has lost in many Western countries (Horsburgh, 1995). Cooper Marcus and Barnes (1999) also discussed the early history of healing gardens in their book, "Healing Gardens: Therapeutic Benefits and Design Recommendations" (Fairchild, 2011: 13). Recent researches in environmental psychology have also illustrated that responding to human needs such as peace, contemplation and meditation, self-knowledge, and self-healing influence stress reduction and promote individual and social mental and physical health (Kabiri \& Balilan, 2015: 5). Those landscapes can provide urban spaces, parks \& gardens in cities that have an opportunity to interact with nature (Pazhuhanfar et al., 2018: 79).

Iran has a valuable natural and cultural heritage called the Persian Garden, an efficient model for applying healing garden design ideas (Mardami et al., 2014: 60). Persian gardens were formed by climate, culture, politics, security conditions, and other relevant features. Water in the Persian garden use in various ways, such as fountains, springs, etc. (Khoshouie, Alborzi, 2010: 412 \& Göker, 2017: 661). It provides inner space experience and stimulates the five senses of users through their physical systems, color, light, plant, water. The combination of water, plants, and space in the Persian gardens show the original concept of these gardens, which are a relief and human-calm. By linking those with, semantic dimensions, the environmental mental health of the users could improve (Shahcheraghi, 2009; Soltanzadeh, 2003; Divandari \& Emamian, 2016). City parks provide significant environmental benefits, such as air and water purification and reduction of urban heat islands where people can relieve their emotions and anxiety (Jeon \& Hong, 2015: 100; Nourani Moghadam, 2017: 2). According to Defra (2007), wellbeing defined as a positive social and mental state; it is not just the lack of pain, discomfort, and incapacity (Koninjnendijk et al, 2013: 6).

According to Cooper Marcus and Barnes's 1995 theory, healing releases from physical symptoms of the disease, reducing nervous pressure and increasing an individual's wellbeing (Nili et al, 2013: 39). The use of the garden as a place of healing traced back to the early cultures of Asia, Greece, and Rome. Nasar (1998) speculated that the positive emotional experience has associated with nature may mediate the therapeutic effect (Han, 2010: 3). Faba (2002) said that the Healing garden is the place to reduce the stress of the user by using a variety of natural elements (Momtaz, 2017: 1865). Natural components such as green space, flowers, water, and sunlight enhance the restorative effect of garden users and improve their fluency (Ulrich, 1999a).

According to Momtaz (2017) Studies, successful healing gardens have the following characteristics: An increasing sense of control, the distribution of different plant species, minimize environmental disturbances, accessibility to nature, encouraging exercise, social support (Momtaz, 2017: 1865). Pouya (2017) also introduced healing gardens features such as Feeling secure, considering the needs of different social groups, accessibility, the possibility of various activities, privacy, social interaction, children's play, visual perception. Climate and the presence of green plant species and also interacting with nature, creating an environment for social gathering, acquaintance Silence and distance from machine noise, peace, and security, legibility, and clarity are characteristics of the healing landscapes. (Mardomi et al, 2015: 59). Ulrich (1999 b) considers the making of a sense of control, privacy, social support, distribution of different plant species, creation of positive distractions, encouraged to practice as characteristics of healing landscapes. Marcus and Barnes (1999) added some parameters of healing gardens, which are relaxing in a stressful environment, use natural elements and display water, encourage wildlife in the environment, stimulate the use of the senses, consider different social groups, and making creative use of color and light. (Marcus \& Barnes, 1999). Also, preserving the spiritual character of the 
space, displaying the life cycle, and minimizing ambiguity are among the characteristics of these places (Vapaa, 2002; Stigsdotter, 2005; Stark, 2013).

On the other hand, David Canter, a pioneer in the conceptual studies of urban architecture and design, views the urban landscape as a place consisting of three intertwined dimensions, perception, action, and physical attributes (Canter, 1977). In other words, the essence of the healing landscapes could be the result of the components that Put under the three visual, functional, and semantic dimensions of the environment. Therefore, Diagram number one, considering the components discussed in different healing studies based on Canter model of space, has been proposed as a theoretical framework for the research.

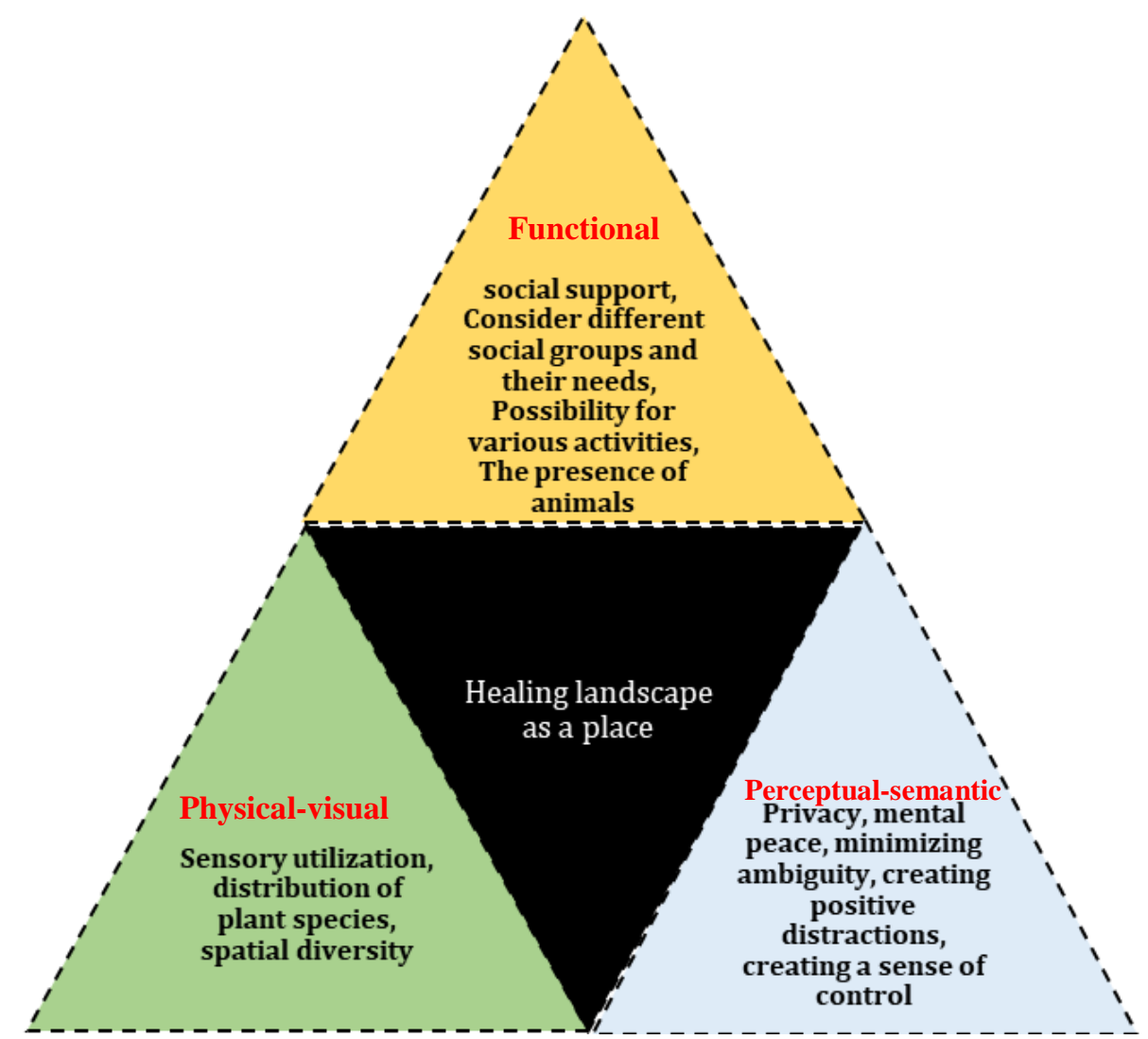

Figure 1. Theoretical Research Framework, Environmental Parameters Affecting the Healing Landscape Pattern Source: Authors

In recent years, a reasonable amount of research conducted into the area of the Persian garden, its landscape, and community health. Many projects in the field of health, well-being in urban parks, hospitals for monks, in an enclosed garden focused on healing approaches. (AyalaAzcárraga, Diaz, \& Zambrano, 2019; Kim \& Jin, 2018; Gerlach et al., 1998 ). Saeidian (2016), consider that healing gardens are the most adaptive with the Persian garden pattern among the other therapeutic gardens. Abdollahi (2015) presented the principles for urban landscape design based on the characteristics of successful Persian healing gardens. In general, each study considers the set of factors to be effective in healing. However, the gender of people dealing with the environment and these healing properties in the circumstances has not addressed yet. The present research seeks to investigate the effect of users' gender on the healing parameters of landscapes with different structural patterns (geometric and organic). So the question is, what is the function 
of the healing landscape components based on the Canter Place model among people of different genders? And how has the organization of these landscapes affected men and women in Azadi Park and Eram Garden? For this purpose, two samples of healing landscapes selected Eram Garden (as Persian Garden type) and Azadi Park (as an Urban Park type).

\section{METHOD}

The present study is applied research. This study's methodology is analytical, and the use of researcher-made questionnaires has collected the descriptive data. 80 questionnaires were filled out by attendees in Eram Garden and 128 in Azadi Park. The questionnaire involved demographic information and indicators measurements based on a five-point Likert scale. The validity of the content of the questions confirmed by experts and its reliability were assessed by using Cronbach's alpha test (alpha coefficient of 0.91). Due to Cronbach's alpha, the correlation among the indicators is high, and the research model is considered desirable. The research questionnaire includes demographic information, and two questions about the aim and frequency of urban green spaces visit. Other questions were about the healing dimension, physical-visual (3 indicators), functional (4 indicators), perceptual-semantic (5 indicators). SPSS 23 software was used to analyze the data to evaluate the effect of healing components among men and women in two samples, UNIANOVA single-variance analysis test used.

To inquire about the research issue, Eram garden, and Azadi park were selected as samples. Eram Garden is one of the most successful Persian gardens of the Seljuk period. This the garden was built at the order of Atabak, the ruler of Fars, in the sixth century (Arianpour, 1986: 308). This garden's it's structure has a major longitudinal axis defined by the wide middle pathway and the row of tall trees and the entrance to the garden and the fountain and the middle ponds as well as the pavilion and buildings on it (Alai, 2009: 8). It now used as a botanical garden. This garden has spaces, including a gem museum (in the middle of the garden), a traditional café called "Sharbatkhane" (place for serving different herbal juices), photography and craft booth, a fish pond (attached to the Eram garden area), sitting areas, walkways with shade trees and more. Azadi Park is also one of the most extensive and oldest park in Shiraz, which opened and operated in 1966. The diverse physical, functional, and semantic spaces within it used for a variety of age and sex ranges. Figures 1 and 2 show the two samples studied, together with their pictures.
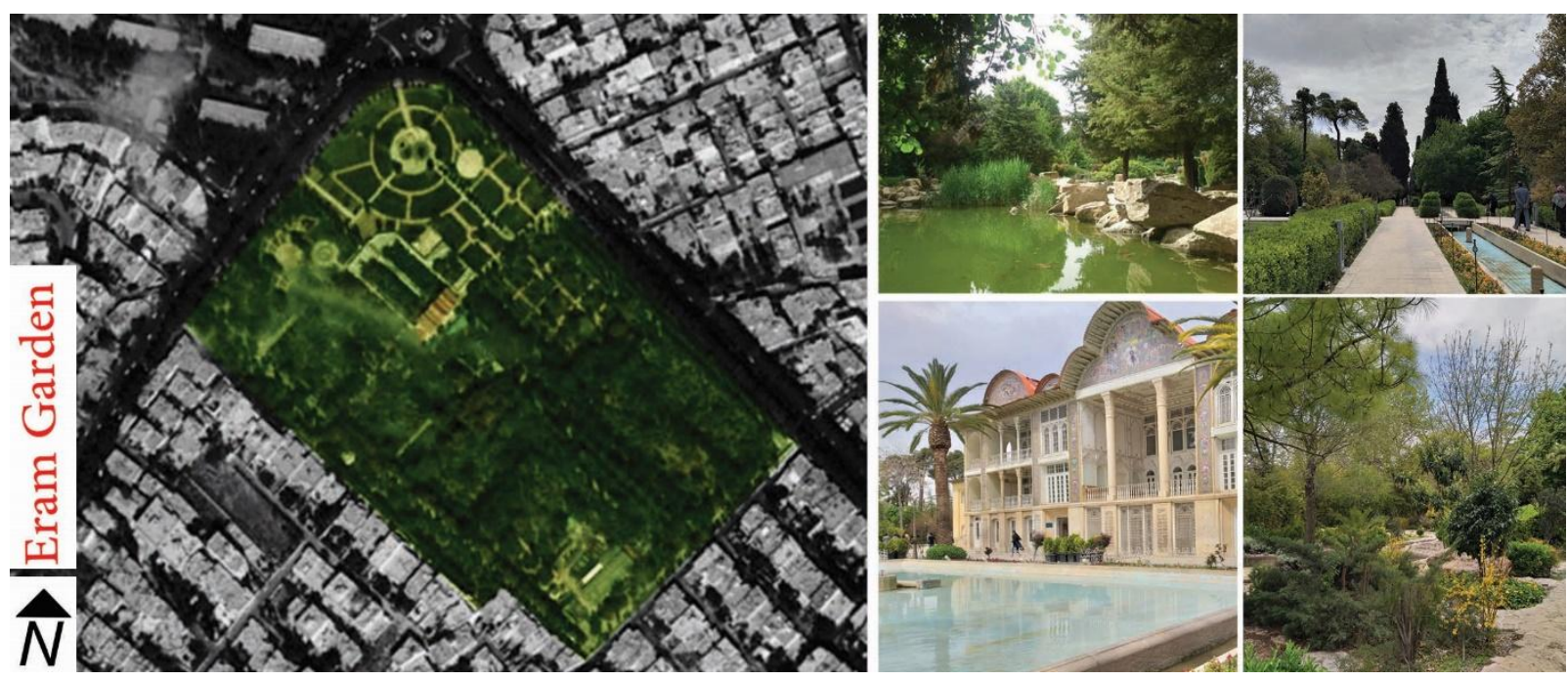

Figure 2. Aerial Photo of Eram Garden and Pictures of its Space.

Source: Authors 

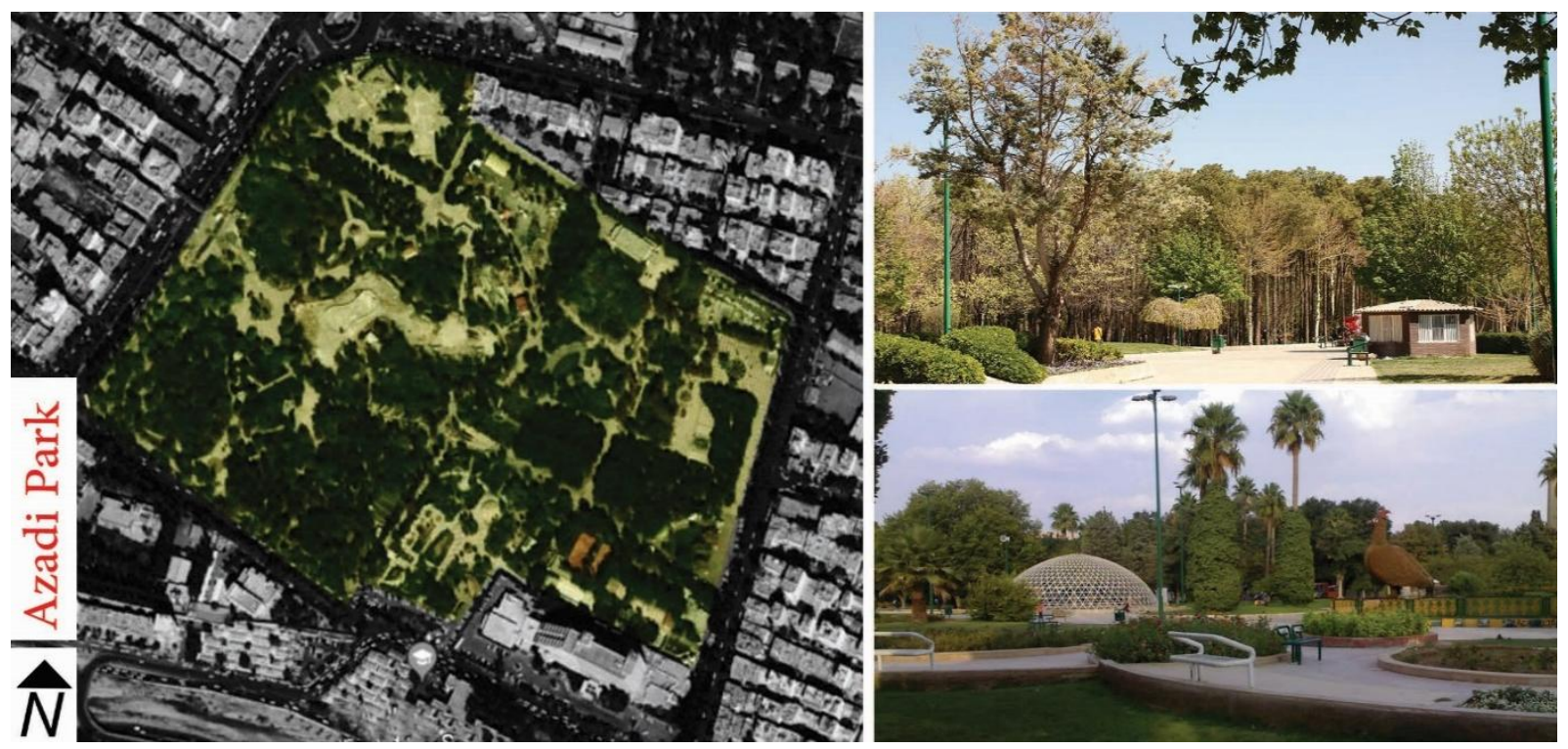

Figure 3. Aerial Photo of Azadi Park and pictures of its Space.

Source: Authors

\section{RESULT AND DISCUSSION}

Univariate analysis of variance (ANOVA) where the dependent variable was the total score of the effect of healing parameters obtained from the questionnaire and the independent variables were location and gender of users was conducted to evaluate the research's issue in the two samples. According to Table 1 and considering that the significance level of the test is less than 0.05 , the interaction between gender and location and the simultaneous effect of these two variables on physical-visual dimension parameters is not analytically significant (sig $>0.05$ ). In other words, in these parameters, the healing effect of the environment is the same for both men and women in Eram Garden and Azadi Park.

Table1. UNIANOVA Test- the effect of the healing dimension among men and women

\begin{tabular}{c|c|c|ccc}
\hline \multirow{2}{*}{ Healing dimension } & \multicolumn{4}{c}{ Gender/ location } \\
\cline { 2 - 6 } & $\begin{array}{c}\text { Partial Eta } \\
\text { Square }\end{array}$ & Sig. & F & $\begin{array}{c}\text { Mean } \\
\text { Square }\end{array}$ & $\begin{array}{c}\text { Type III Sum of } \\
\text { Square }\end{array}$ \\
\hline Perceptual- semantic & 0.000 & 0.005 & 0.003 & 0.062 & 0.062 \\
\hline Physical- visual & 0.005 & 0.481 & 0.500 & 0.291 & 0.291 \\
\hline Functional & 0.003 & 0.04 & 0.314 & 0.141 & 0.141 \\
\hline
\end{tabular}

Source: Authors

Additionally, the effect of gender on physical-visual parameters of healing was not significant (sig> 0.05). That is, there is no difference between men and women in the perception of these parameters. On the other hand, the simultaneous effect of gender and location on perceptual-semantic and functional parameters were significant (sig <0.05). Each of the parameters discussed below. According to Table 2, there was a meaningful difference between men and women in the parameters of privacy, mental peace, and minimization of ambiguity from perceptual-semantic dimension, and different activities and considering different social groups and their needs from functional dimensions. 
Healing Landscapes: The Effects of Its Parameters on Different Gender (Case Study: Eram Garden \& Azadi Park of Shiraz-Iran)

Mina Razmara*

Hajar Asadpour, Malihe Taghipour

Table 2. Effect of Healing Parameter Among Men and Women

\begin{tabular}{|c|c|c|c|c|c|c|}
\hline \multirow[b]{2}{*}{ Healing dimension } & \multirow[t]{2}{*}{ Healing parameter } & \multicolumn{5}{|c|}{ Gender/location } \\
\hline & & $\begin{array}{c}\text { Partial } \\
\text { Eta } \\
\text { Square } \\
\end{array}$ & Sig. & $\mathrm{F}$ & $\begin{array}{l}\text { Mean } \\
\text { Square }\end{array}$ & $\begin{array}{l}\text { Type III } \\
\text { Sum of } \\
\text { Square }\end{array}$ \\
\hline \multirow{3}{*}{ Functional } & Social support & 0.009 & 0.336 & 0.942 & 0.445 & 0.445 \\
\hline & Possibility for various activities & 0.001 & 0.005 & 0.068 & 0.53 & 0.53 \\
\hline & $\begin{array}{c}\text { Consider different social groups and } \\
\text { their needs }\end{array}$ & 0.001 & 0.01 & 0.058 & 0.052 & 0.052 \\
\hline \multirow{3}{*}{ Perceptual- semantic } & Privacy & 0.005 & 0.008 & 0.484 & 0.288 & 0.288 \\
\hline & Mental peace & 0.014 & 0.023 & 1.424 & 1.098 & 1.098 \\
\hline & Minimize ambiguity & 0.002 & 0.041 & 0.159 & 0.149 & 0.149 \\
\hline
\end{tabular}

Source: Authors

To investigate the differences between these parameters, the analytical mean of each in Eram Garden and Azadi Park were measured in men and women. According to Table 3, in Azadi Park, the component of privacy and mental peace for women were less than men, while minimizing ambiguity for men reported more than women. There was also less opportunity for women to engage in different activities and less consideration to women's various social groups in Azadi Park than men. In the perceptual-semantic dimension, in the Eram Garden, the analytical mean of each group was approximately equal and top to the average. While participating in different activities and understanding different social groups and needs from functional parameters, analytical averages for both groups were approximately equal to and below the average.

Table 3. Descriptive Values of Healing Landscape Dimension

\begin{tabular}{|c|c|c|c|c|c|c|}
\hline \multirow{3}{*}{ Gender } & \multirow{3}{*}{ Location } & \multicolumn{5}{|c|}{ Mean } \\
\hline & & \multicolumn{3}{|c|}{ Perceptual-semantic } & \multicolumn{2}{|c|}{ Functional } \\
\hline & & $\begin{array}{l}\text { Mental } \\
\text { peace }\end{array}$ & Privacy & $\begin{array}{l}\text { Minimize } \\
\text { ambiguity }\end{array}$ & $\begin{array}{l}\text { Possibility for } \\
\text { various } \\
\text { activities }\end{array}$ & $\begin{array}{l}\text { Consider different } \\
\text { social groups and } \\
\text { needs }\end{array}$ \\
\hline & Azadi park & 2.2248 & 2.1958 & 2.7591 & 2.4302 & 2.2145 \\
\hline \multirow[t]{3}{*}{ Female } & Eram garden & 4.1594 & 4.2609 & 3.8901 & 2.2826 & 2.4317 \\
\hline & Total & 3.5505 & 3.1018 & 3.3215 & 2.3045 & 2.3751 \\
\hline & Azadi park & 3.6190 & 3.2552 & 3.9851 & 3.7143 & 3.2571 \\
\hline \multirow[t]{2}{*}{ Male } & Eram garden & 4.1176 & 3.8235 & 4.1032 & 2.4706 & 2.6173 \\
\hline & Total & 3.8421 & 3.4711 & 4.0112 & 3.0516 & 2.9819 \\
\hline
\end{tabular}

Source: Authors

Gender discourse in the garden and the park has a different function. Concerning the research hypothesis on the effect of the gender variable on the understanding of healing parameters, according to Table 4, women's perception of perception-semantic and functional parameters in Azadi Park is lower than that of men. Women find Azadi Park as an ambiguous and confusing place where they sometimes find it challenging to navigate, while less so in the Eram Garden. In this regard, we can mention the psychological characteristic of men and woman's understanding that women have a discrete thought while men have a holistic perception. They, therefore, have different routing behavior and use distinct visual elements when traveling in different directions. Women feel confused in an environment of too much detail, but men can easily 
concentrate their sight. Space visualization is one of the men's most impressive abilities. Women are better at visualizing two-dimensional shapes, and men are better at visualizing three-dimensional objects. Men have a stronger sense of direction than women. Due to better spatial visualization, men can identify cognitive mapping, position, and significant elements. On the other hand, women are confused in complex spaces; long hours in such places are not pleasant for them. To make the place suitable for women, space needs to have simplicity and monotony, so that environment perception will not have confusion. Recognizable elements can also use to reduce women's weakness.

Women feel more secure in spaces where transparency and visual continuity are present. Areas that are not $\operatorname{dim}$ and solitude and have appropriate lighting. Components such as the quality of night lighting, visual connectivity with the environment, physical supervision, security, and privacy are among the elements that directly affect the mental peace that is desirable in the Eram Garden, while Azadi Park has not satisfied women's needs.

To have privacy in space, it is necessary to design separated and delimited areas for individual, semi-public, and public behavioral settings. Azadi Park landscape pattern has created some hidden scary spaces, which was disappointing to provide privacy and exacerbated the sense of fear and disrupted the psyche of the audience. One of the most important causes of this problem is their poor lighting at night. According to Azadi park observations, lights installed are higher than the trees, so the tree's shade creates a dark, intimidating environment that can also be a source of mass. In the Eram garden, territory differentiation created through different plants, floor level height diversity, furniture's shape, and various spaces (communal space around fish ponds) has been able to provide a pleasant retreat for people at different times of the day. Proper lighting, control, and using time of the space and the enclosure of the garden have also been effective in providing privacy.

Specific places might be tendered based on occupants' gender or the different activities in which they occupied. This facility is easily accessible to men in Azadi Park, and they participate in various sports activities. But women find it difficult to join in different activities and believe that the spaces intended for physical activity (playgrounds, sports, etc.) Are more available to men. Since there is no ban on the use of spaces for women, this seems to be more of a cultural (mental) aspect, and women do not feel comfortable using public spaces for physical activities and prefer to be in places where women are. They avoid being in places that reserved for men, especially younger ones.

In contrast, there was no significant difference between male and female activities and behaviors in the Eram Garden. Since the Eram Garden is one of the historic gardens, the main reason people visit this area is to experience the nature of the garden and participate in cultural activities. Besides, the Eram Garden is an enclosed space with an entrance control system and limited time use during the day ( 8 AM-7 PM) and, unlike the urban parks, does not allow users to have some behaviors (tenting, playing, lying on grassy ground, etc.) And it has diminished the freedom of men's acts and put them in the same situation with women who culturally constrain in the park. 


\section{CONCLUSION}

Healing landscapes can relieve stress, soothe, and restore health. They can provide in openair urban areas, parks, and gardens in cities. Psychological differences betwen men and women cause each differently acts; in their surrounding environment, they have different feedback on the healing dimensions of the environment. Therefore, it is necessary to consider the gender difference in space perception. In this study, regarding the gender discourse in healing landscapes, the performance of different aspects of landscape healing parameters in different structural patterns (geometric and organic) was investigated.

According to the results, there were no differences in the physical-visual dimension between men and women, and these parameters included the physical components of the place which the visitor's senses. Vegetation types and spatial variability have the same effects between men and women. However, perceptual-semantic and functional-functional components have different effects between men and women. Women's perceptions of perceptual-semantic and functionalfunctional components in Freedom Park are lower than men's. In Azadi Park (organic model), privacy and peace of mind were less for women, and minimizing ambiguity for men had the least effect on understanding the healing qualities of the environment. Regarding the psychological differences between men and women and different women's activities are less likely to occur, it is essential to design the details of elements (decorations, materials diversity, colors, etc.) Alongside the space generalities (continuity, enclosure, and so on). So, both men and women can enjoy being in these places. Men adopt the characteristics of space to their perception, thereby increasing the efficiency and acceptance of space for gender groups. Moreover, improving connectivity between users and healing landscapes makes people from different gender willing to spend time there.

\section{ACKNOWLEDGMENT}

The authors would like to thank all the people who helped us in providing this paper. The constructive comments provided by the anonymous referees are also gratefully acknowledged.

\section{REFERENCES}

Abdollahi, R., Aminzadeh, B., Shahcheraghi, A., \& Etesam I. 2015. Developing the Components of Healing garden design in Iran and its Application in the Design of Urban Open Spaces. Urban Management, No. 39:317-345. Alai, A. 2009. Diversity of Design in Historical Gardens of Shiraz. Soffeh, no. 49(19): 5-20.

Arianpour, A. 1986. A Study in Recognition of Iranian and Historical Gardens of Shiraz. Tehran: Farhangsara. Ayala-Azcárraga, C. Diaz, D. \& Zambrano L. 2019. Characteristics of Urban Parks and Their relation to User Well-Being. Landscape and Urban Planning, No.189: 27-35.

Canter, D. 1977. The psychology of place. London: St Martin'S Press.

Cooper Marcus, C., \& Barnes, M. 1999. Healing Garden: Therapeutic Benefits and Design Recommendation. New York: John Wiley, and sons.

Divandari, J. \& Emamian Z.S. 2016. The Role of Structural Elements of the Persian Garden in Mental Health. The Iioab Journal, No. 7:21-27.

Fairchild, H. R. 2011. Designing a Healing Garden For Three Patient Populations Based on Research, Theory, Observation, and Interviews. PhD Thesis, University of Georgia.

Gerlach-Spriggs, N., Kaufman, R.E., \& Warner, S.B. 1998. Restorative Gardens: The Healing Landscape. New Haven: Yale University Press. 
Göker, P. 2017. An Analysis of Water Features in Persian gardens; Bagh-e Shahzadeh. International Journal of Environmental Science and Development, No. 8 (9): 661-664.

Han, K.T. 2010. An Exploration of Relationships Among the Responses to Natural Scenes: Scenic Beauty,

Preference, and Restoration. Environment and Behavior. No. 42 (2): 243-270.

Horsburgh, C.R. 1995. Healing by Design. The New England Journal of Medicine. No. 333, 735-740.

Jeon, J.Y. \& Hong, J.Y. 2015. Classification of urban park soundscapes through perceptions of the Acoustical Environments. Landscape and Urban Planning, No.141: 100-111 .

Kabiri, B. \& Balilan L.2015. The Analysis of The Iranian Garden-Therapy Process Based on The Perceptual Ecologic Theory. Journal of Art and Architecture. No.1 (1): 5-13.

Khoshouie, M.R. \& Alborz, F. 2016. The Feasibility of Using Persian Garden Elements in Today's Urban

Areas toward Social Interaction Enhancement. Journal of school health. No.71 (3): 4-101.

Kim, D. \& Jin, J. 2018. Does happiness data say urban parks are worth it?. Landscape And Urban Planning. No.178: 1-11.

Konijnendijk, C.C. Annerstedt, M. Nielsen A.B. \& Maruthaveeran S. 2013. Benefits of Urban Parks: a Systematic Review. A report for IPFRA.

Marcus, C.C. 2000. Gardens and Health. International Academy for Design and Health. No.5: 61-69 .

Mardomi, K. Mirhashemi, S. \& Hassanpour, K. 2015. Persian Garden as Healing Garden an Approach with

Islamic Influences. Journal of Research in Islamic Architecture. No.5: 67-81.

McDowell, C.F. \& McDowell, T.C. 1998. The sanctuary garden. New York: Fireside book.

Momtaz, R.I. 2017. Healing Gardens-A Review of Design Guidelines. International Journal of Current Engineering and Technology. No. 7 (5): 1871-1864.

Nili, R. Nile, R. \& Soltanzadeh H. 2013. Studying the Application of Healing Landscapes in Persian Gardens. Journal of Bagh-E Nazar. No. 9 (23): 65-74.

Nourani Moghaddam, A. 2017. The Role of Urban Furniture in Citizenship / Comfort (Case Study: Kowsar

Park Shirvan). Geography, Civil and Urban Studies. No. 4(3): 1-13.

Pazhuhanfar, M. Mustafa kamal, M.S. Maulana, S. \& Mariapan M. 2018. Relationship Between Predictors of

Visual Preferences and Restorative Components Of The Urban Natural Landscape, Studies of Architecture.

Urbanism and Environmental. Sciences Journal. No.1 (2): 79-85.

Pouya, S. 2017.Healing Gardens in The Megacities; an Example Of Tehran. Journal of Urban Academy, No.10

(2): 139-156.

Saeidian, N. Memarzia, K. Zakeri, S.M. \& Habibi A. 2016. Comparative Study of Persian Garden Landscape

Pattern Versus Four Kinds of Therapeutic Gardens. Journal of Urban Landscape Research, No. 2(4): 81-93.

Shahcheraghi, A. 2009. Analyzing The Perception Process of Persian Garden's Environment, According to

The Ecologic Psychological Theory. Hoviat Shahr, No. 3(5): 71-84.

Shahcheraghi, A. 2015. Paradigms of Paradise, Recognition and Re-Creation of The Persian Garden. Tehran: Jahad Daneshgahi.

Soltanzadeh, H.2003. From Gardens To Public Yards (Park). Iranian Journal of Anthropology, No. 1(4): 91-

113.

Stark, A. 2013. Creating an Outstanding Environment with Geomancy and Feng Shui: guidelines for Healing

Gardens. Available at http://www.alexstark.com/guidlines/healing-gardens (accessed 15 July 2013)

Stigsdotter, U.A. 2005. Landscape Architecture and Health, Evidence-Based Health-Promoting Design, and

Planning. Ph.D. Thesis, Department Of Landscape Planning Alarm, Swedish university of agricultural science.

Ulrich, R. S. 1999a. Effects of Gardens On Health Outcomes: Theory and Research. In C.

Ulrich, R.S. 1999b. Effects Of Interior Design on Wellness: Theory And Scientific Research. Journal Of Health

Care Interior Design, No. 3: 97-109.

Vapaa, A.G. 2002. Healing Gardens: Creating Places for Restoration, Meditation, and Sanctuary. Ph.D. thesis.

Virginia Polytechnic Institute and State University. 